\title{
Nejsevernější muzeum světa - zujte se, prosím!
}

Veronika Nirnbergová

\section{The Northernmost Museum of the World - Shoes Off, Please!}

Annotation: The article deals with the northernmost museum of the world located in Svalbard capital, Longyearbyen, West Spitsbergen. Particular focus is on the methods used in the exhibitions in order to efficiently showcase the Arctic environment.

Key words: Longyearbyen, Svalbard, Spitsbergen, Arctic, museum, Svalbard Global Seed Vault, mining

Při vstupu do Svalbard Museum - muzea v Longyearbyenu, hlavním městě souostroví Svalbardu - nehledejte uzamykatelné šatní skříňky. Ve dvou a půl tisícovém špicberském městě (Longyearbyen, 2021) - přes léto - s téměř nulovou kriminalitou nejsou třeba. A pokud se na rozdíl od zvyklých domorodců ostýcháte odložit si do police své boty, jsou tu k zapůjčení návleky. Hned u stojanů na odložení pušky...

Na první pohled nijak okázalá, přesto největší budova ve městě spojující univerzitu, výzkumné prostory a muzeum byla roku 2005 rozšírena výstavbou nové části, jejíž konstrukce vizuálním i technologickým řě̌ením ${ }^{1}$ vhodně zapadá do arktického prostředí. Prostory samotného muzea, které př́stavbou profitovaly, nabízejí kompletní pohled na špicberskou historii, přírodní podmínky i kulturu.

Návštěvníka jistě po vstupu do výstavní části zaujme moderní řešení prostoru (obr. 1), barevně laděného do tmavých odstínů, ovšem dostatečně prosvětleného nerušivým osvětlením. Atmosféra diváka

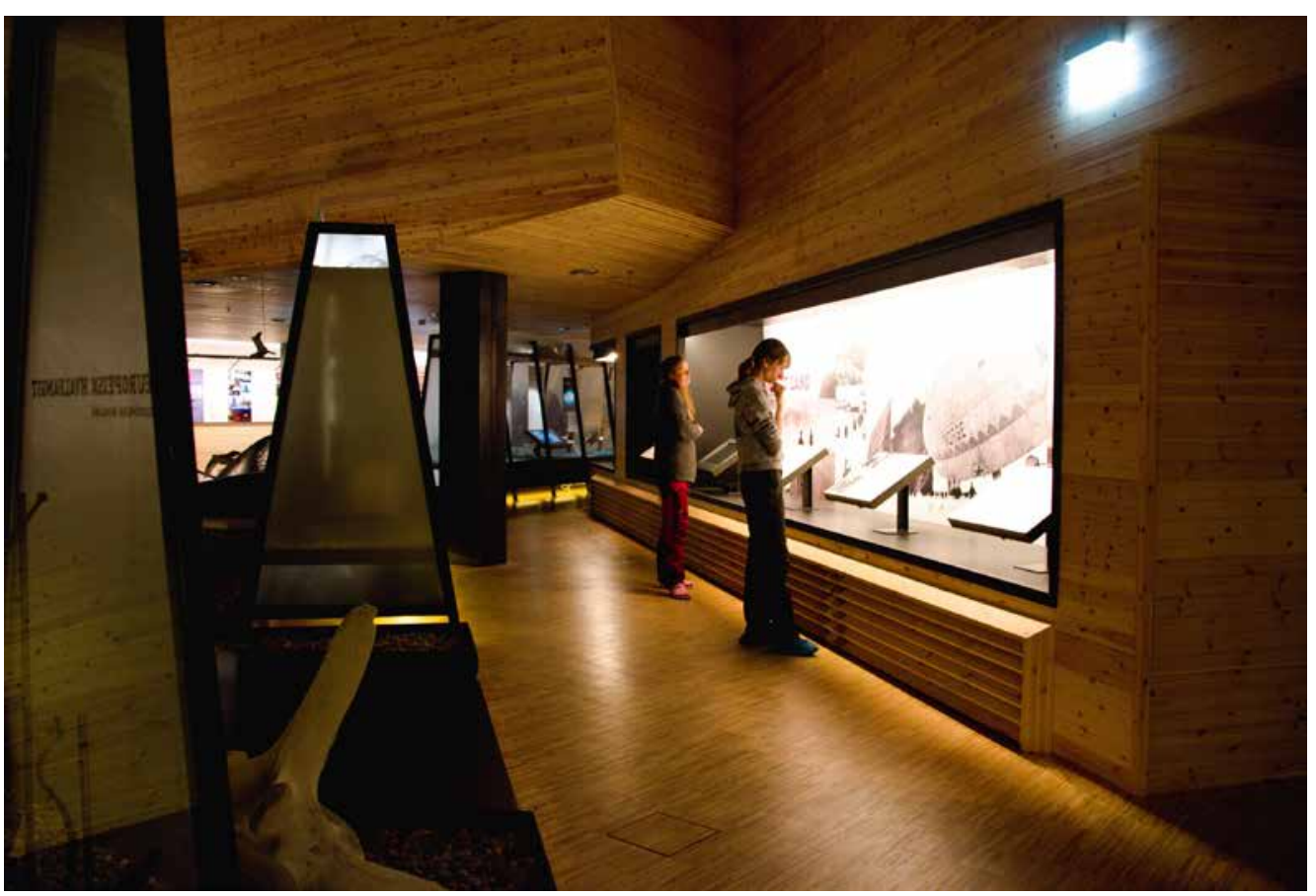

Architektonické řešení interiéru.
1 Architektonický projekt je podrobněji popsán na https:// wWw.archdaily.com/3506/ svalbard-science-centre-jva

Mgr. Veronika Nirnbergová Katedra výtvarné výchovy PdF Univerzity Palackého v Olomouci; veronika@nirnberg.cz 

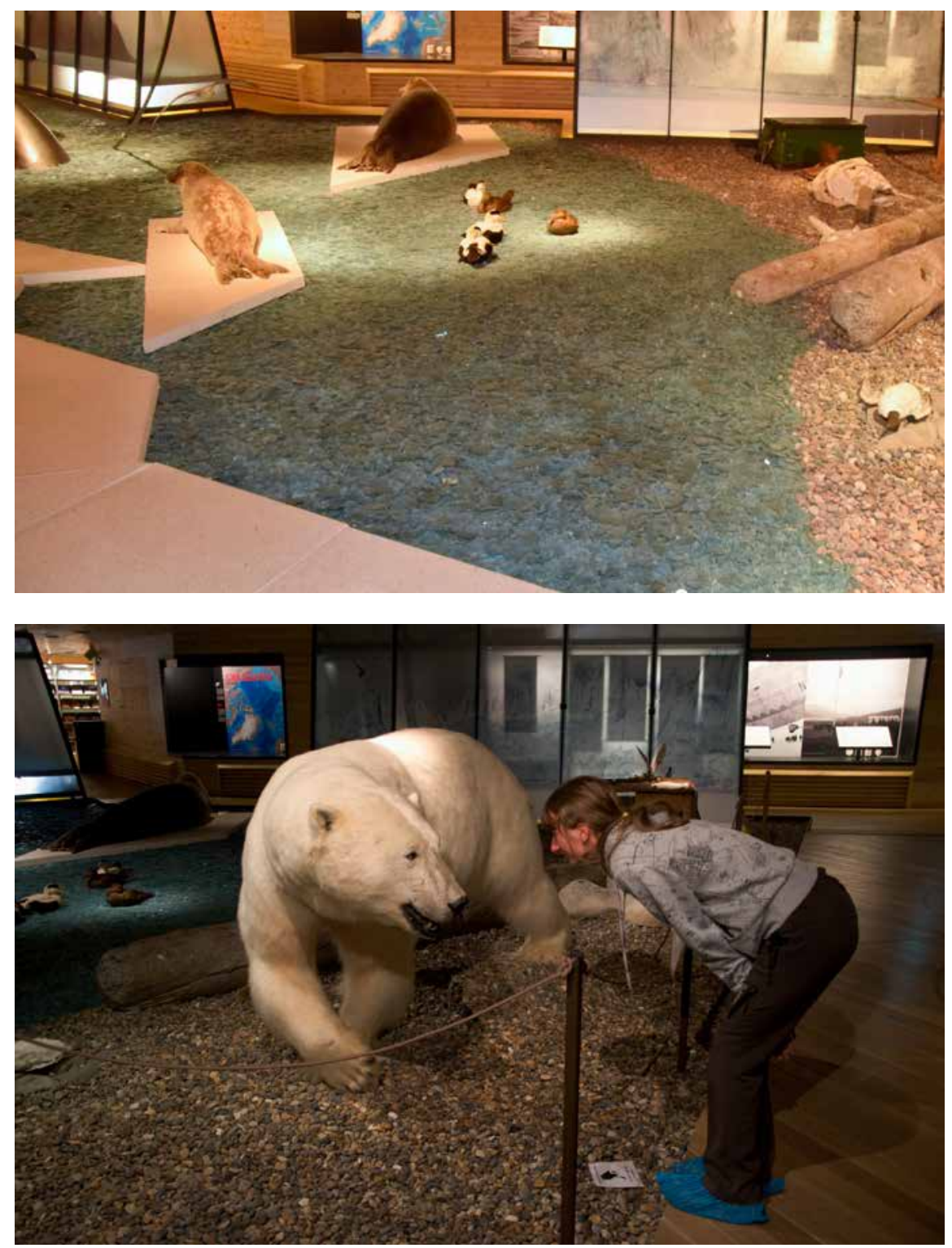

Imitace arktické prírody.

Mrazivý pohled šelmy

2 Výraz „visitor friendly” odkazuje na maximální snahu o prizpůsobení se potrebám návštěvníka.

3 Barentsburg, asi 450 obyvatel (Barentsburg, 2021).

4 Malá ruská osada využívaná do roku 1962 jako prístav

pro expedování vytěženého uhlí v sousední lokalitě Grumantbyen (Stange, 2019). téměř okamžitě vtáhne do poznání běžného života, trávení pracovního a volného času i klimatu a živočišné říše tady, daleko za polárním kruhem.

Část podlahy dokonale simuluje ledové kry na vodě (obr. 2). Věrohodnost podtrhují umně vyvedení živočichové, kteří svým přesvědčivým výrazem jasně dávají najevo, kdo je tu na návštěvě. Přestože už v letištní hale vás po př́letu na ostrov uvítá vycpaný lední medvěd překvapivých rozměrů, tady, v jeho simulovaném přirozeném prostředí je odzbrojující pohled zcela dokonalé kopie šelmy daleko zlověstnější (obr. 3). U dřevěné chatky opodál však dovádějí i malí roztomilí bílí chlupáči. Přesto, nebo možná právě proto, že napodobeniny těchto majestátních živočichů vypadají naprosto přesvědčivě, zdá se proměna malých huňáčků $\mathrm{v}$ respekt vzbuzujícího obra jen těžko uvěřitelná.

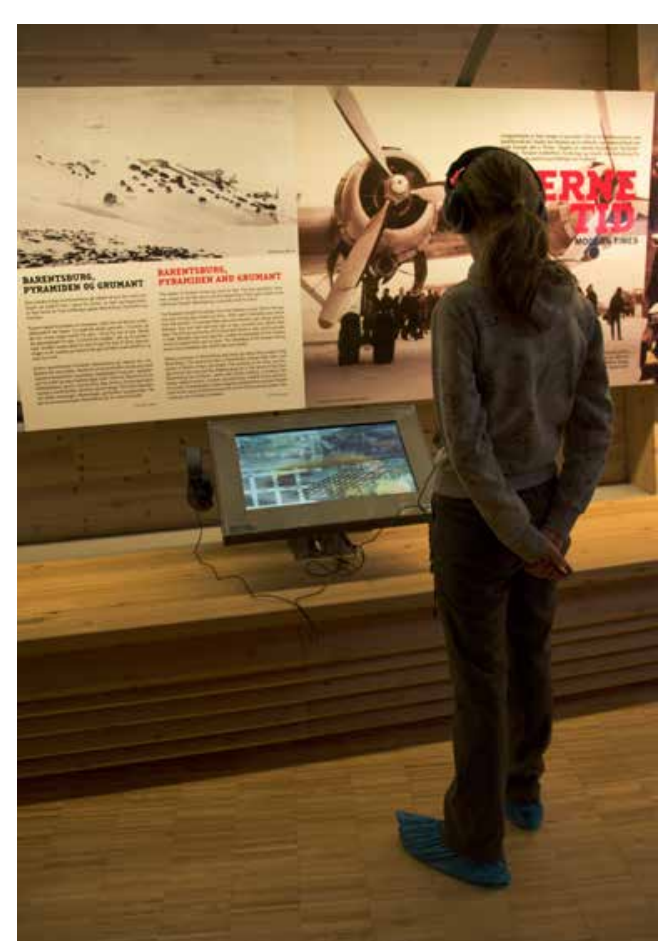

Audiovizuální prvky.

Může se jevit až překvapující, jak je celý výstavní prostor muzea na 78. severní rovnoběžce protkán moderními technologiemi. Nutno podotknout, že všechno je velmi „visitor friendly“2 - at' už jde o řadu audiovizuálních prvků, videí, mluveného slova ve sluchátkách nebo „pouhé“ popisky exponátů. Angličtina je spolu s norštinou samozřejmostí. Můžete např́klad zhlédnout krátký film o hornictví v druhém nejlidnatějším osídlení souostroví $^{3}$ se zvukovým doprovodem ve sluchátkách (obr. 4), takže vás nebude rušit dětský obdiv mrože vykukujícího opodál $\mathrm{z}$ "vody" (obr. 5).

K lehkému fyzickému odpočinku mohou zájemci využít knihovnický kout s pohodlnými polštáři k sezení a svazky místních novin a dalších publikací $\mathrm{k}$ nahlédnutí. Regál s knihami opticky odděluje tento malý prostor od zbytku expozice, přestože je přiznaně jeho součástí (obr. 6). Posezení v tomto klidném koutku tak může být př́jemným zpestřením během vstřebávání silných podnětů.

Ostatně na vlastní kưži se prostorově méně výrazní zájemci dokonce mohou vplazit 


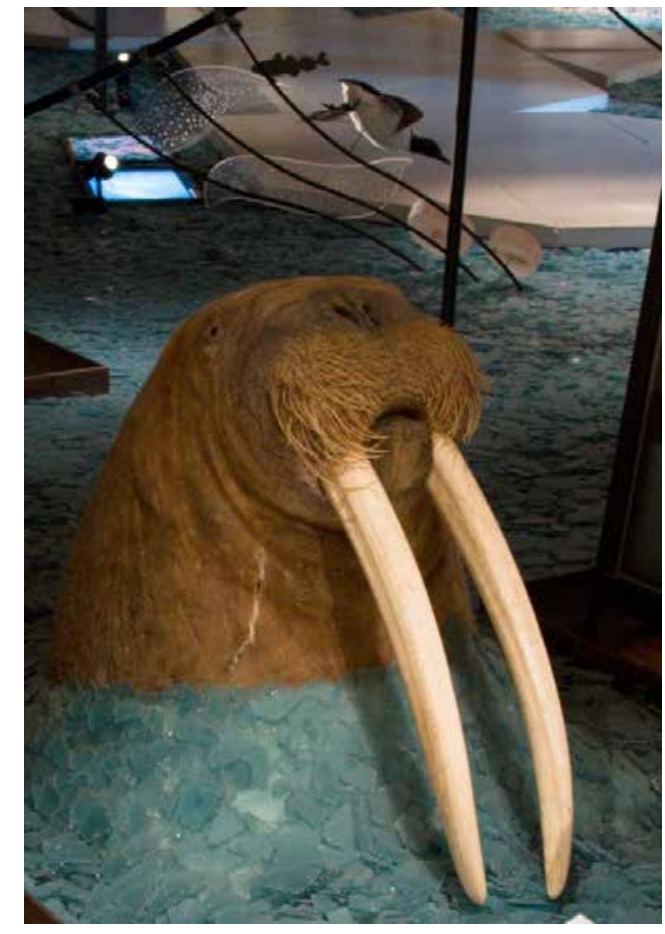

Napodobenina hlavy mrože vykukujícího $z$ vody.

do kopie hornické štoly (obr. 7). Nenadále ukončená hornická činnost $\mathrm{v}$ okolí nedaleké Colesbukty ${ }^{4}$ a Pyramidenu ${ }^{5}$ zapř́ícinila, že prímo $\mathrm{v}$ těchto lokalitách můžete dnes navštívit malá města duchů, která se sama stala "muzei.“" Také na ně upozorňuje část výstavy. A chcete-li stavět něco do kontrastu $s$ touto tajemnou etapou mrazivé historie ostrova, pak vás jistě osloví designově nadčasový exponát, kterým je model moderního podzemního komplexu Špicberského globálního úložiště semen vybudovaného $v$ letech 2006 až 2008 za městem. Ačkoliv jde prý o jedno z nejstřeženějších míst na Zemi ukrývající rozmanitost rostlinných semen z celého světa, zbloudilci přicházející z hor budou plot z jižní strany hledat marně.

Muzeum, které v roce 2008 získalo cenu Evropského muzea roku ${ }^{6}$ (The Council of Europe Museum Prize, 2021), si klade za cíl poskytnout široké a ucelené poznání arktické prírody a historie (Svalbard Museum). Tuto ambici přesvědčivě naplňuje.

Pozorný návštěvník muzea při zavazování svých tkaniček u východu už jistě ví, proč
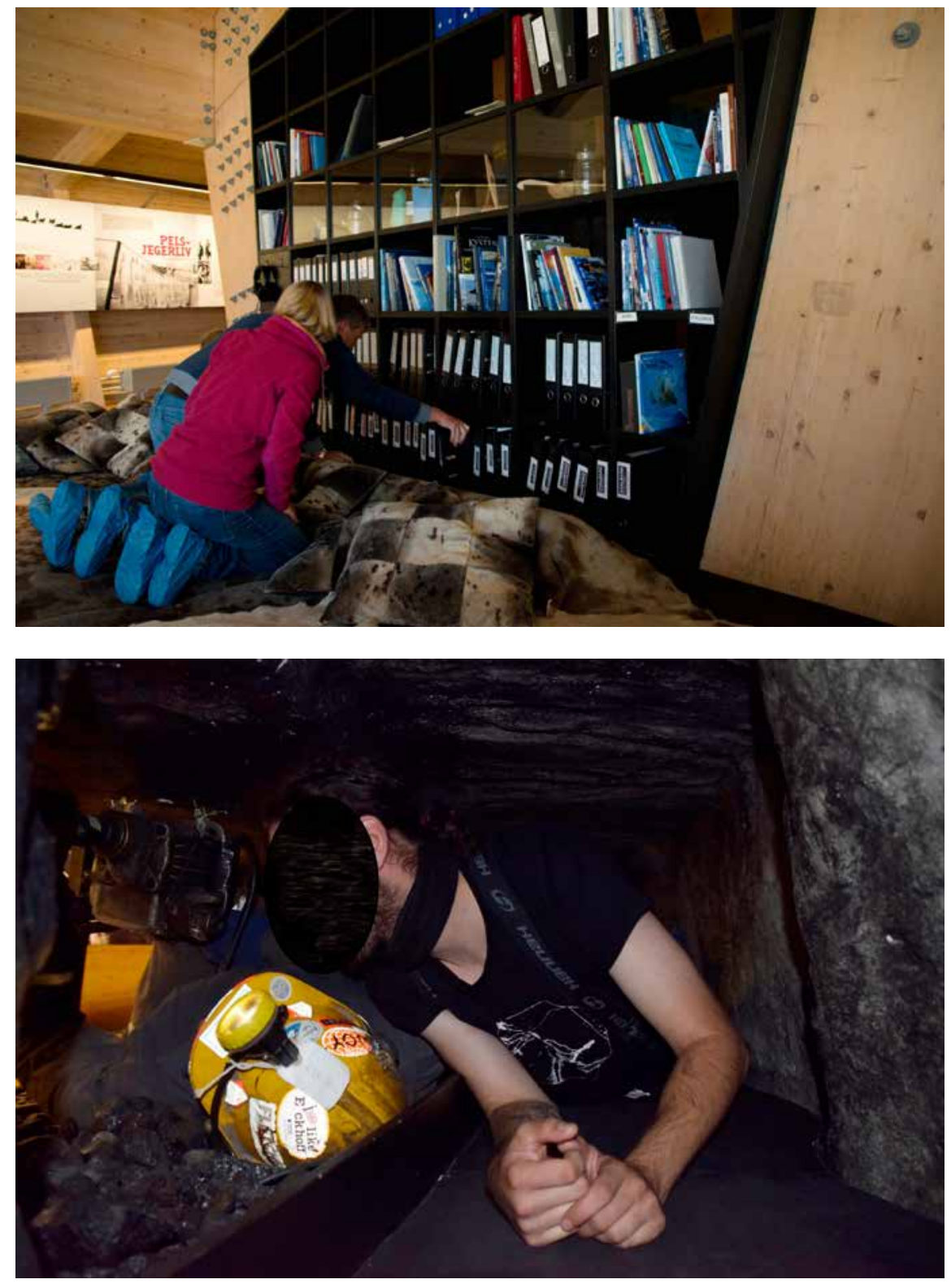

ho při vstupu do všech veřejných budov muzeum nevyjímaje - cedulky nabádají k vyzutí bot. Každý tu totiž ctí starou hornickou tradici. A také už cizinec ví, že pokud se rozhodne zajít si ke zmiňované "semenné bance“ nebo k areálu s obřími satelity za městem, půjčí si se souhlasem guvernéra naproti muzea zbraň. Všichni se tu totiž kvůli občasným srážkám s ledním medvědem loučí pozdravem „Be safe“.7

\section{Zdroje:}

Longyearbyen [online]. Visit Svalbard. 2021. [cit. 2021-10-01]. Dostupné z: <https://en.visitsvalbard.com/visitor-information/ destinations/longyearbyen>.

Barentsburg [online]. Visit Svalbard. 2021. [cit. 2021-10-01]. Dostupné z: <https:// en.visitsvalbard.com/visitor-information/ destinations/barentsburg>.

\section{Knihovnický kout.}

Kopie hornické štoly.

5 Pưvodně švédské osídlení, později odkoupené Sovětským svazem k provozování těžby $v$ okolí. $V$ roce 1998 bylo rozhodnuto o ukončení těžby a prí rychlé evakuaci z důvodu odplouvání lodě byl Pyramiden bleskově opuštěn.

6 European Museum of the Year Award - ocenění udèlované muzeím, která jsou pro návštěvníky přitažlivá a nabízejí "jedinečnou atmosféru, nápaditou interpretaci a prezentaci, kreativitu a inovaci $v$ naučných a sociálních aspektech" (EMYA).

7 Bud'v bezpeči. Opatruj se. 
Pyramiden [online]. Visit Svalbard. 2021. [cit. 2021-10-01]. Dostupné z: <https://en.visitsvalbard.com/visitor-information/ destinations/pyramiden>.

STANGE, Rolf. Colesbukta [online]. Spitsbergen I Svalbard. Poslední změna: 2019-04-24. [cit. 2021-10-01]. Dostupné z: <https://www.spitsbergen-svalbard. com/photos-panoramas-videos-and-webcams/spitsbergen-panoramas/colesbukta.html>.

EMYA. [online]. ICOM Česká republika. [cit. 2021-10-01]. Dostupné z:

$<$ https://icom-czech.mini.icom.museum/ souteze/emya/>.

The Council of Europe Museum Prize [online]. European Museum Forum. 2021. [cit. 2021-10-01]. Dostupné z: <https://www. europeanforum.museum/en/winners/ council-of-europe-museum-prize/>.

Svalbard Museum [online]. Visit Norway. [cit. 2021-10-01]. Dostupné z: <https://www.visitnorway.com/listings/ svalbard-museum/199334/>. 